\title{
Heavy Metal Removal from the Water of the River Nile Using Riverbank Filtration
}

\author{
Mohamed H. Hegazy ${ }^{1, *(\mathbb{D}}$, Ahmed Essam ${ }^{1}\left(\mathbb{D}\right.$, Ashraf Y. Elnaggar ${ }^{2}$ (D) and Enas E. Hussein ${ }^{3, *(\mathbb{D})}$ \\ 1 Department of Civil and Construction Engineering, The British University in Egypt (BUE), \\ Cairo 11435, Egypt; ahmed146946@bue.edu.eg \\ 2 Department of Food Nutrition Science, College of Science (Previously Chemistry), Taif University, \\ P.O. Box 11099, Taif 21944, Saudi Arabia; aynaggar@Tu.edu.sa \\ 3 National Water Research Center, P.O. Box 74, Shubra El-Kheima 13411, Egypt \\ * Correspondence: mohamed.hegazy@bue.edu.eg (M.H.H.); enas_el-sayed@nwrc.gov.eg (E.E.H.)
}

Citation: Hegazy, M.H.; Essam, A.; Elnaggar, A.Y.; E. Hussein, E. Heavy Metal Removal from the Water of the River Nile Using Riverbank Filtration. Water 2021, 13, 3642. https: / / doi.org/10.3390/w13243642

Academic Editor: Daniel D. Snow

Received: 30 October 2021

Accepted: 14 December 2021

Published: 17 December 2021

Publisher's Note: MDPI stays neutral with regard to jurisdictional claims in published maps and institutional affiliations.

Copyright: (c) 2021 by the authors. Licensee MDPI, Basel, Switzerland. This article is an open access article distributed under the terms and conditions of the Creative Commons Attribution (CC BY) license (https:// creativecommons.org/licenses/by/ $4.0 /)$.

\begin{abstract}
Riverbank filtration (RBF) is considered as a natural treatment process. During this process, a group of chemical, physical, and biological processes occur when water moves through the soil along the bank of the River Nile, which can act as a conventional treatment process. RBF is one of the most effective solutions that the Egyptian government and responsible parties should embrace. Egypt has started to use the RBF technique widely in many sites through the path of the River Nile. This study provides a detailed analysis of the RBF technique; it represents the outlet quality of the water in a study performed on the River Nile. The effect of RBF on water quality can be measured using the software designed for this study. The study's main aim is to improve the water quality of the River Nile by removing heavy metals from the water by using an effective and fast method of treatment, which is riverbank filtration. The results of the research's experimental study show the average percentage of metal removal for iron, cobalt, lead, zinc, and copper are $74.04 \%, 74.44 \%$, $70.72 \%, 75.1 \%$, and $70.8 \%$, respectively. These results have proved that RBF acts as a substantial barrier versus heavy metals.
\end{abstract}

Keywords: riverbank filtration; water quality; water quality index; treatment process; weighted arithmetic method

\section{Introduction}

Riverbank filtration is categorized as one of the natural and sustainable techniques that can be used for water purification. This filtration system is mainly based on the action of the soil of the banks of the water source as a natural filtration surface to the infiltrated water [1]. In Egypt, the growing need for drinkable water has promoted the use of riverbank filtration as an economical method for water purification [2]. The main aim of this research is to focus on protecting and improving the quality of water by spotlighting pollutants that affect water and how to eliminate them by using a compelling method to treat water that is considered a solution to water problems. The advancement of the technology of riverbank filtration is one of the most considerable and quickest solutions that should be embraced by the government and responsible parties [3]. Riverbank filtration is considered a regulatory system used to eliminate heavy metals and microorganisms and is environmentally friendly because of the absence of chemicals in this technique [4]. It is very important to investigate the degree of efficiency of the riverbank filtration process before applying, especially in developing counties that have a high-water demand [5]. The utilization of RBF has expanded widely in Egypt, many governorates in Egypt have started to use this filtration system such as Giza, Beni Suef, Minia, Suhag, and Qena.

The quality of water is one of the essential factors that affect living organisms whether used for drinking, home, or factories. Water quality expresses the circumstances of the water's inclusive biological, physical, and chemical characteristics. Riverbank filtration is 
more advantageous than traditional water resources development modes in that it improves water quality by percolation [6]. By detecting the concentration of it is parameters and components it is possible to compare these results with standard components for potable water [7]. Freshwater supports our plants, as well as animals and humans. It is definite that our activities and actions cause an effect on water quality, whether positive or negative [8]. With time, the quality of water is threatened due to all kinds of sources of pollution such as nutrients and phosphates that come from fertilizers, industrialization, irrigation, and agricultural activities, which places humans at risk [9]. As a result of increasing populations and industries, the size of a wide range of pollutions such as water pollution, air pollution, and soil pollution are huge compared to the past [10]. For drinking water quality, riverbank filtration is guaranteed as an effective method for removing many water contaminants. Along the stream of one of the Indian rivers (Yamuna), the removal efficiency of dissolved organic matter using RBF exceeds the 50\% removal [11]. In some conditions, riverbank filtration is used as a pre-step in the water purification process, for better water quality, and energy cost reduction [12].

Surface water contains specific concentrations of heavy metals such as Iron (Fe), Mercury (Hg), Copper (Cu), Nickel (Ni), Zinc ( $\mathrm{Zn})$, Cobalt $(\mathrm{Co})$, and Lead $(\mathrm{Pb})$ that may cause many diseases to human beings. Due to the toxicity of heavy metals, various techniques have been used to remove them from water such as adsorption, membrane filtration, precipitation, and Flocculation [13]. Most of the dissolved iron in water forms stable compounds with fulvic acid, that can move with the water stream into the intake wells during riverbank filtration [14]. The site conditions, type, and concentration of heavy metals are the most influencing factors on the efficiency of removal using riverbank filtration. In addition, it has been declared that the water characteristics such as $\mathrm{pH}$ value, dissolved oxygen, and dissolved organic matter concentrations have a major impact upon the adsorption process of heavy metals during riverbank filtration [15]. Sediments on the riverbed or aquifer may contain a sufficient concentration of iron, manganese minerals, and hydroxides that may contaminate water by dissolving [16]. Redox conditions are one of the dependent factors on the riverbank filtration RBF process especially on the removal efficiency of micropolluants [17]. The media of redox is mainly identified by the process of microbial respiration, at which the natural organic matters NOM is the electron donor and oxygen, ni-trate, Mn(III/IV)- and Fe(III) hydroxides or sulfate are the electron acceptors [18].

In Egypt, there are many types of contamination that affect water sources such as heavy metals. In our country, we have a lot of sources of freshwater in comparison with many other countries. They have to begin using efficient and cost-effective water purification methods, such as riverbank filtration [19]. Riverbank filtration is a technique that provides an ordinary filtration process. During this process when groundwater passes through the soil along the bank of the Nile, a group of chemical, physical and biological processes takes place, which are essential components of the treatment process [20]. The environmental parameters such as biodegradation and adsorption of organic contaminants are still typically unquantified [21]. Some of the literature has investigated the degradation and sorption of various emerging organic contaminants (EOC) such as adsorbable organic halogens (AOX), naphthalenedisulfonic (NDSA), phenazon, clindamycin, carbamazepine, sulfa-methoxazole (SMOX), methyl tert-butylether (MTBE), and adsorbable organic iodines (AOI). They observed that mostly a decrease in EOC concentrations have happened after riverbank filtration.

Treatment is a process to improve water quality to match with the water quality standards that is suitable for human uses. The volume of treated water depends on the citizen's consumption per day of water for drinking, cooking, and reactional purposes. Responsible ministry or the government should choose a suitable treatment system by taking into consideration the cost and design period.

Countries that have insufficient funds cannot build an effective treatment plant; therefore, it is hard to find safe water for human use. To balance out this issue, there are many 
economical solutions to treat water, such as using riverbank filtration and slow sand filter in the filtration stage [22]. The treatment process is designed to make sure that water whether it is wastewater or potable water is safe for human uses in all it is forms. Treatment is considered the second stage in the water supply system. The quantity of water, geological conditions, and pollution on the surface bank are important factors that may hinder the success of the riverbank filtration process [23]. Also, the seasonal variations may cause a decrease in RBF efficiency due to the change in microbial diversity during wet and dry seasons [24]. Clogging in the riverbed is an important factor that affects the quantity and quality of water during the RBF process [25].

Both human-made and natural impacts can affect the quality of water. The natural treatment uses natural geology in order to purify water without chemicals. Nowadays, many countries worldwide need to improve the quality of water without harm to the environment. There are many advantages for the natural treatment process such as; it is not a complicated process, there is no need for very skilled employees, it is not expensive like conventional treatment processes, it can be used widely, and it is easy to maintain. However, these processes are not suitable for all situations such as if there is a lot of and various chemical contaminations in the water. In this case, there must be human intervention [26].

There are many examples of natural treatment that can remove contaminations efficiently, such as lagoons and RBF [1]. Riverbank Filtration is a technique delivering a natural filtration process. Compared with the traditional treatment process, riverbank filtration is very economical. The total cost of the RBF unit is about 250,000 EGP, while the price of a conventional treatment plant is 10 million EGP [27].

The main objective of this research is to study the removal behavior of different heavy metals from water coming from the river Nile. This objective will lead to identifying the possibility of the riverbank filtration process being a reliable and successful technique that can be used separately or as a pretreatment stage to remove heavy metals from water.

\section{Materials and Methods}

\subsection{Work Plan Model}

The algorithm of this study is shown in Figure 1. The working map is ramified into four components. It includes the soil tests, measurement of heavy metals concentration, and the calculation of water quality in addition to the riverbank filtration lab model.

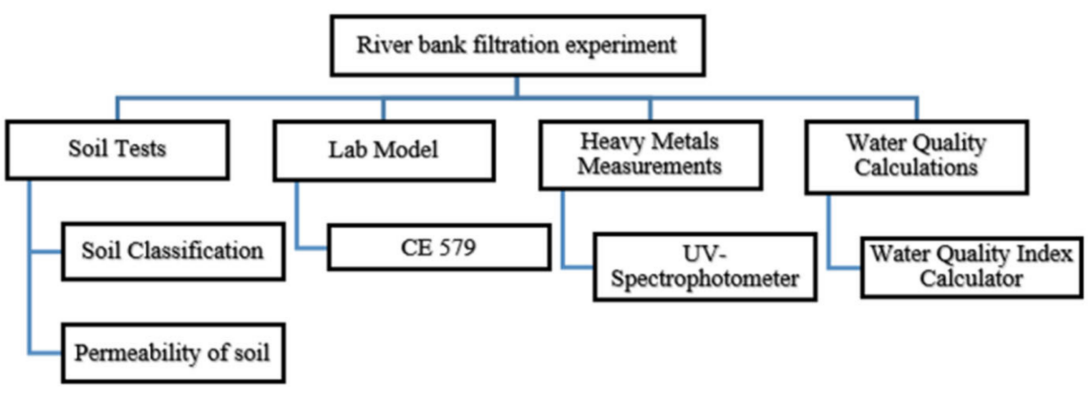

Figure 1. Mind Map of the Study.

This experiment was divided into five runs. In each run, the concentration of the heavy metals is gradually increased starting from a concentration of $1 \mathrm{mg} / \mathrm{L}$ of metal and ending with $5 \mathrm{mg} / \mathrm{L}$. During the experiment two samples were taken daily before the operation of the RBF Unit; and within a period of time, two samples were taken every half an hour. More than two hundred water samples were taken during a working period of 4 months from the inlet and outlet of the lab filtration model (CE 579 Unit). The samples were conveyed to water quality laboratories in the faculty of engineering in Ain shams University (Egypt). In the lab, all the measuring experiments were done to determine the 
concentration of heavy metal in the water before and after filtration to identify the effect of riverbank filtration on the quality of water from the River Nile.

\subsection{Water Characteristics}

Firstly, water samples were taken from the River Nile to be examined to determine and identify its degree of quality. Table 1 represents the results of the water quality analysis of River Nile samples. The results show that most of the measured parameters' average levels are below the standard limits mentioned of the Egyptian Law no. 48/1982, except the Turbidity [28]. The redox conditions or the oxidation-reduction potentials ORP of water during the experiments was ranged between $-65 \mathrm{mv}$ to $-180 \mathrm{mv}$.

Table 1. Raw water characteristics and Egyptian standards limits according to law 48/1982.

\begin{tabular}{cccc}
\hline Parameter & Unit & Range & Egypt Limit \\
\hline Temperature & ${ }^{\circ} \mathrm{C}$ & $17-28$ & $5{ }^{\circ} \mathrm{C}$ above normal \\
\hline pH & & $7.4-8.6$ & $7.0-8.5$ \\
\hline Turbidity & $\mathrm{NTU}$ & $2.7-11$ & 5 \\
\hline TDS & $\mathrm{mg} / \mathrm{L}$ & $143-317$ & 500 \\
\hline Conductivity & $\mu \mathrm{S} / \mathrm{cm}$ & $280-430$ & \\
\hline Alkalinity (CaCO3) & $\mathrm{mg} / \mathrm{L}$ & $112-170$ & 200 \\
\hline Total Hardness (CaCO3) & $\mathrm{mg} / \mathrm{L}$ & $110-258$ & 200 \\
\hline BOD5 & $\mathrm{mg} / \mathrm{L}$ & $1.2-7.7$ & 6 \\
\hline COD & $\mathrm{mg} / \mathrm{L}$ & $2.4-11.8$ & 10 \\
\hline DO & $\mathrm{mg} / \mathrm{L}$ & $7.2-12$ & $\geq 5$
\end{tabular}

Secondly, the concentration of the heavy metals under this study $(\mathrm{Fe}, \mathrm{Co}, \mathrm{Pb}, \mathrm{Zn}$, and $\mathrm{Cu}$ ) was measured in the water samples taken to prepare the water for the experiments according to the fixed concentrations of heavy metals that were previously set for the tests (1 to $5 \mathrm{mg} / \mathrm{L}$ ).

\subsection{Soil Tests}

The site used to take samples of soil for the study was located at $31^{\circ} 14^{\prime} 13.92^{\prime \prime} \mathrm{E}$, $29^{\circ} 57^{\prime} 46.08^{\prime \prime} \mathrm{N}$. These samples were taken for some experimental tests such as soil classification and the permeability of the soil. The soil was sieved and classified according to "ASTM D 2487-06 standard procedure". Also, the concentration of some heavy metals that may be included as soil sediments were examined to make sure that it will not influence the research results. The soil investigation results are shown in Table 2.

Table 2. Soil Characteristics of soil used in River Bank Filtration (RBF) Model.

\begin{tabular}{cccc}
\hline Parameter & Unit & Value & SD \\
\hline Sand & $\%$ & 72 & \pm 5.0 \\
\hline Silt & $\%$ & 12 & \pm 1.5 \\
\hline Clay & $\%$ & 10 & \pm 1.0 \\
\hline Organic Matters & $\%$ & 6 & \pm 0.3 \\
\hline PH & $\%$ & 7.6 & \\
\hline porosity & & 35.75 & \\
\hline Specific Gravity & & 2.5 & \\
\hline
\end{tabular}


Table 2. Cont.

\begin{tabular}{cccc}
\hline Parameter & Unit & Value & SD \\
\hline Dry Density & $\mathrm{gm} / \mathrm{cm}^{3}$ & 1.2 & \\
\hline Void Ratio & & 0.615 & \pm 1.3 \\
\hline $\mathbf{F e}$ & $\mu \mathrm{g} / \mathrm{gm}$ & 32.4 & \pm 0.7 \\
\hline $\mathbf{P b}$ & $\mu \mathrm{g} / \mathrm{gm}$ & 16.25 & \pm 2.1 \\
\hline $\mathbf{C u}$ & $\mu \mathrm{g} / \mathrm{gm}$ & 44.7 &
\end{tabular}

\subsection{RBF Lab Model}

Depth filtration by using soil filters is the main procedure in water purification. The device shown in Figure 2 (CE 579) empowers this procedure to be established. The tower filter pipe is made from a transparent PMMA Plexiglas tube with dimensions $1660 \mathrm{~mm}$ high, and $150 \mathrm{~mm}$ and $200 \mathrm{~mm}$ internal and external diameter, respectively. The soil filter is integrated into the piping system with flange connections at the upper and lower end. The flanges on the tube side are also made of PMMA and are bonded to the tube. The counter flanges are made of PVC and are secured with knurled screws. The flange connections are sealed using rubber sealing rings.

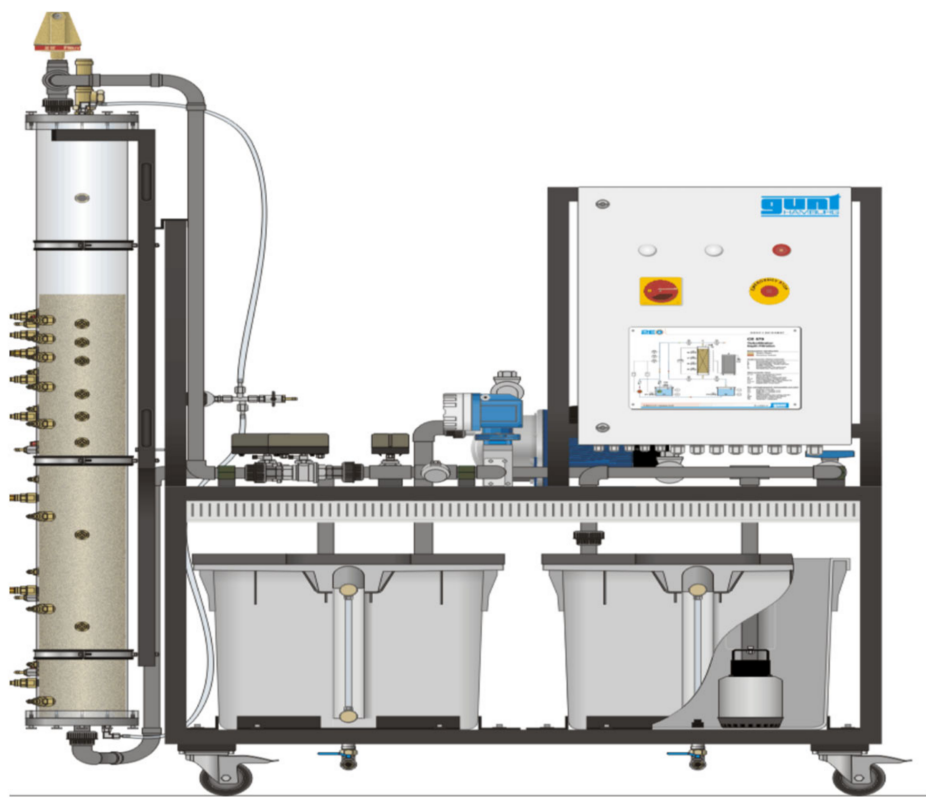

Figure 2. Experimental Filtration Model (CE 579).

The RBF model contains a filter and washing pumps with a maximum delivery rate of 5.0 and $3.0 \mathrm{~m}^{3} / \mathrm{h}$ respectively, under an average pressure of 1.5 bars. The empty bed contact time (EBCT) was based on the bed volume and the filtration rate was $2.16 \mathrm{~min}$. Raw water that is contaminated with impurities and solids is dragged from the upside and moves to a soil filter bed. The solids and impurities are retained due to the raw water passing through the soil filter bed. The water passes due to gravity through the soil filter bed then appears at the bottom of the media. The treated raw water passes through to the outflow tank.

Supplementary solids and impurities are retained in the filter medium (filter bed), so that the resistance is increased. This process is done due to the difference in hydrostatic pressure between the inlet (soil filter) and the outlet. There is a software program used to control the operation and measure the data [29]. 
The system model has four sampling valves. The sampling valves can optionally be integrated into the system. At the end of each valve, there is a lance with small holes through which samples can be taken.

The backwashing process for filter media is done periodically at the end of each run with the specified heavy metal concentration. During the transition stage of changing the type of heavy metal added to water, the soil inside the model is changed with a new soil having the same start-up characteristics to avoid any disturbance that can happen on the measured influent and effluent concentrations. Also, the influent tank is washed with diluted hydraulic acid and distilled water several times before feeding the model with influent water of any working runs.

\subsection{Ultraviolet (UV) Spectrophotometer}

There are many methods to determine the concentration of metals in raw water either with lab instruments such as UV-spectrophotometer or with titration methods. In this study, the UV-spectrophotometer is used to detect the concentration of heavy metals. The process of quantitative determination of heavy metals in the UV-Spectrophotometer occurs when the unknown metals absorb UV light generated from the instrument. The concentration of heavy metals is directly proportional to the intensity of light [30].

\subsection{Water Quality Index (WQI) Calculator}

This software shown in Figure 3 is designed to identify the quality of effluent water obtained from the riverbank filtration unit. The main aim of this software is to determine the quality of water and water quality index quickly without doing manual calculations. Also, to identify the parameter issues or to identify which parameter does not follow the standards, this calculator is designed by using visual basics technology and based on the weighted arithmetic method for water quality (WAWQI) calculation which is one of the widely used water quality indicators (1).

$$
W Q i=\frac{\sum_{i=1}^{i=n} w_{i} \times Q_{i}}{w i}
$$

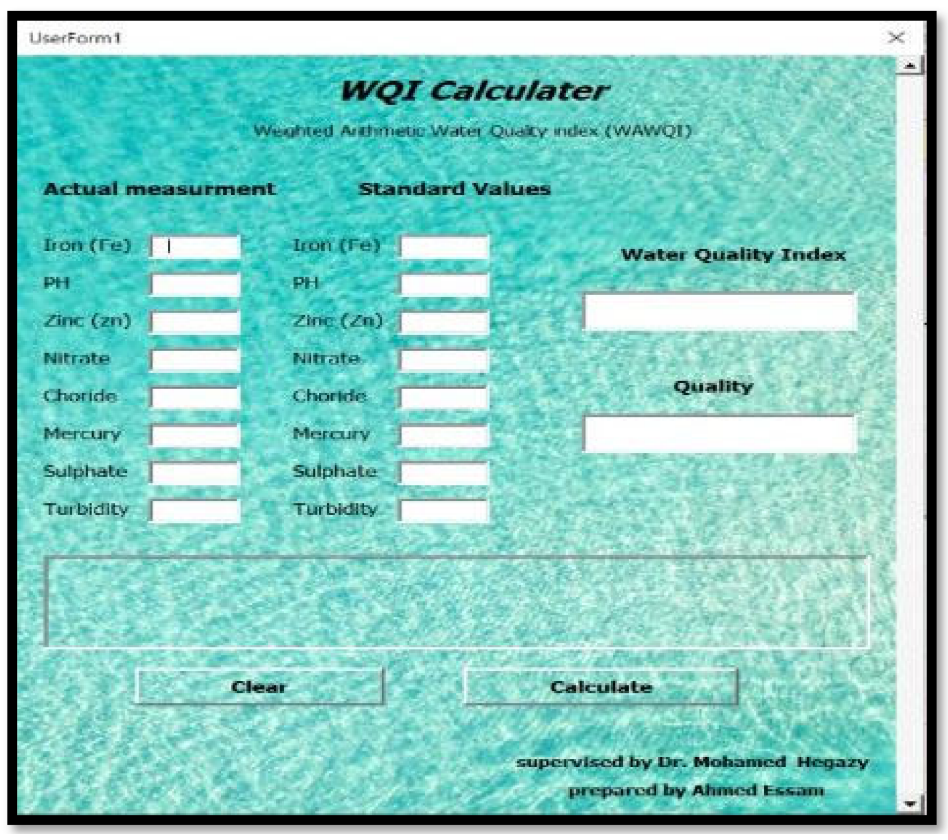

Figure 3. WQI Calculator window phase.

The inputs of this software contain standard values for the parameters suggested by the "World Health Organization" and actual measurement of factors (parameters) that 
were carried out during the experiment. Software inputs parameters can include the concentration of different parameters such as in our study heavy metals $(\mathrm{Fe}, \mathrm{Zn}, \ldots$. ), and also some water characteristics that include $\mathrm{pH}$ value and water turbidity.

On the other hand, there are three outputs obtained from the software; the first one is the water quality index, where there are five categories for water quality index (A, B, C, $\mathrm{D}$, and $\mathrm{E}$ ). These categories can be determined from software by using a group of if-else statements. The second output is the quality of water (first-rate, good, barren, very poor, and not potable). The last output is the parameter issue to determine which parameter does not follow the standards by calculating the difference between the standards values and actual measurement.

\section{Results}

This section represents the results of the riverbank filtration experiment that was made of five runs where each run consisted of 30 samples, which indicate the concentration of heavy metals in the outlet water and the percentage of heavy metal removal. Figures 4-8 show different heavy metals concentrations in water samples through the five runs along the time period for each run. We can observe that the increase of the adjusted heavy metals concentration affects descendingly the removal efficiency.

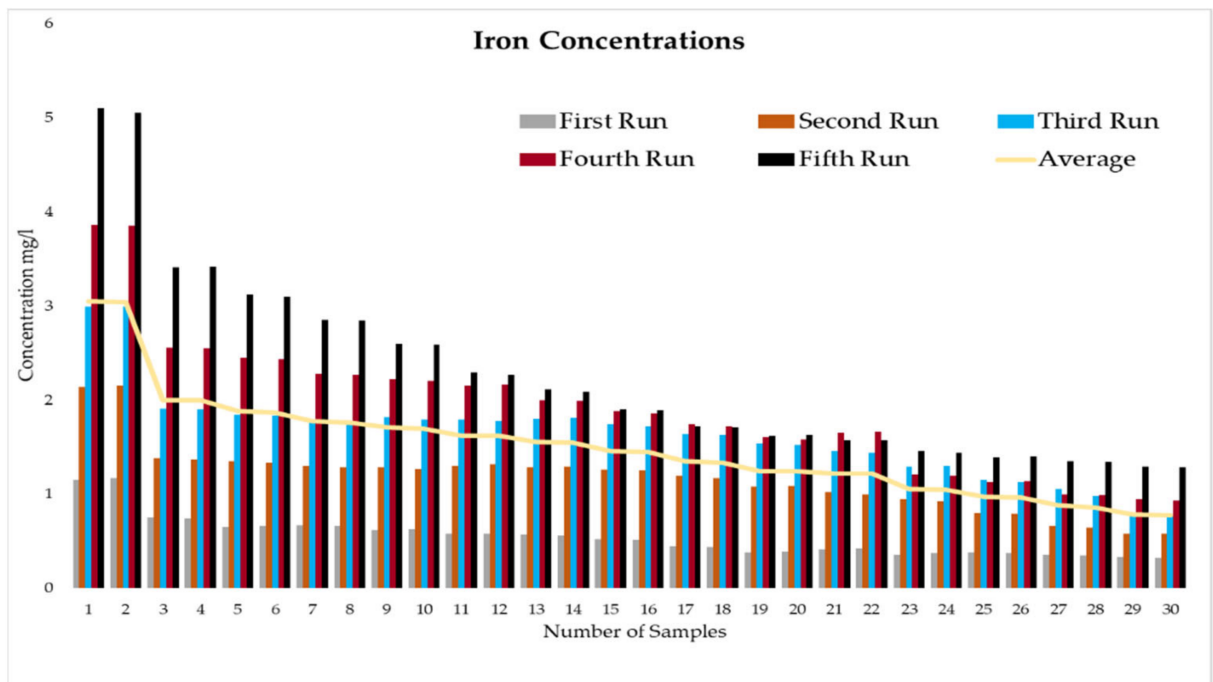

Figure 4. Iron concentration in water samples from RBF model.

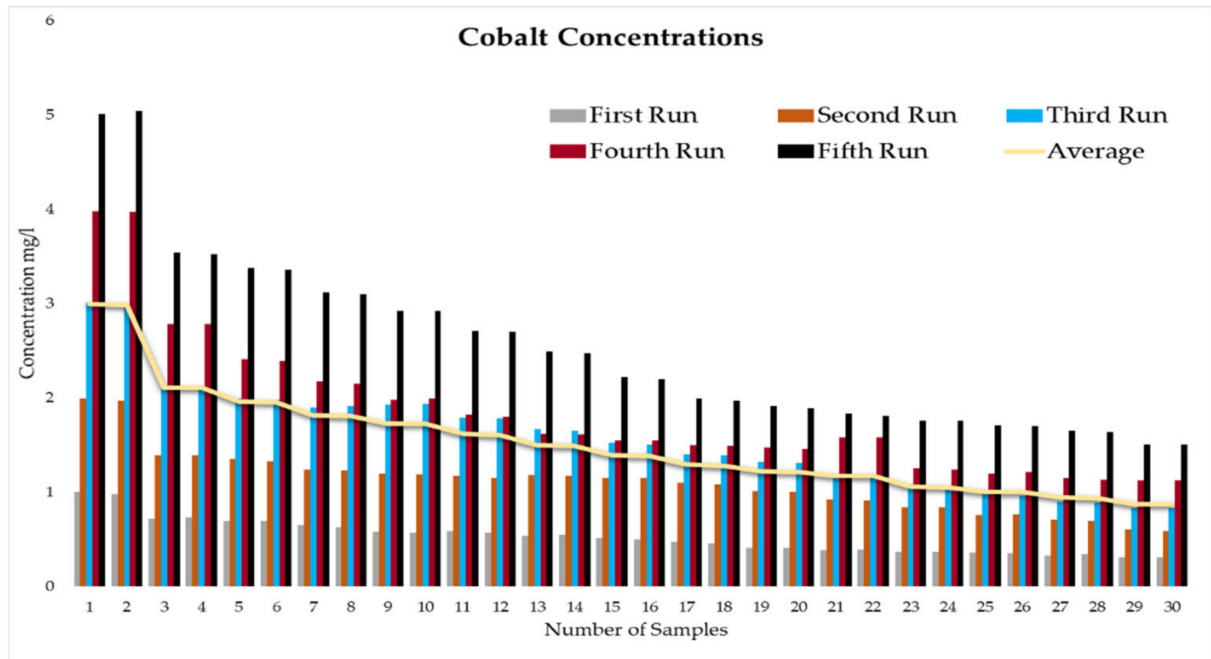

Figure 5. Cobalt concentration in water samples from RBF model. 


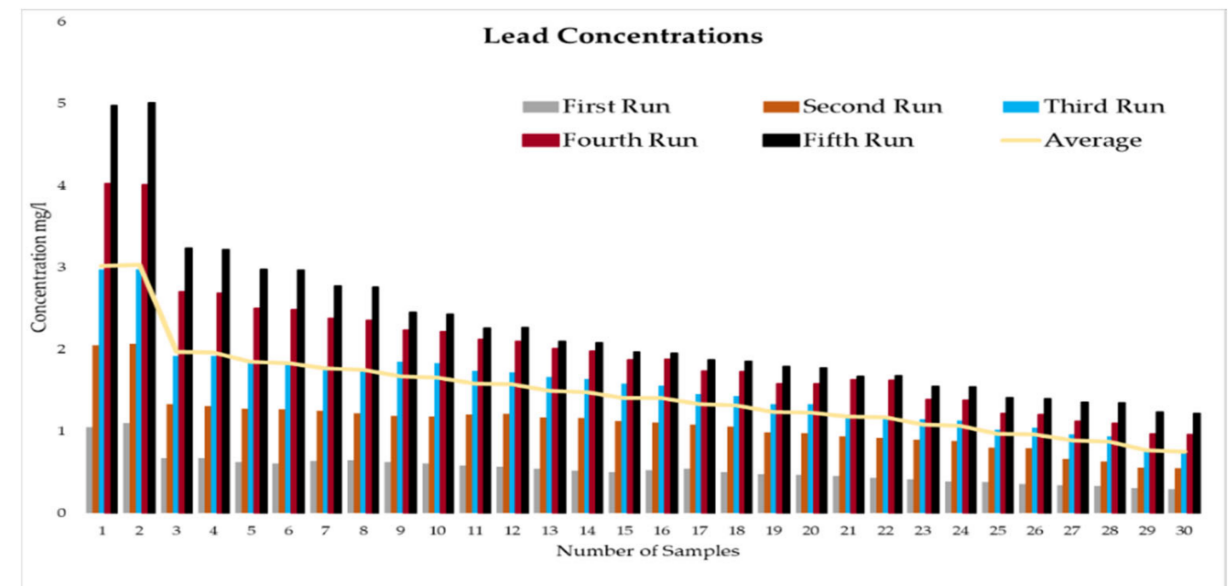

Figure 6. Lead concentration in water samples from RBF model.

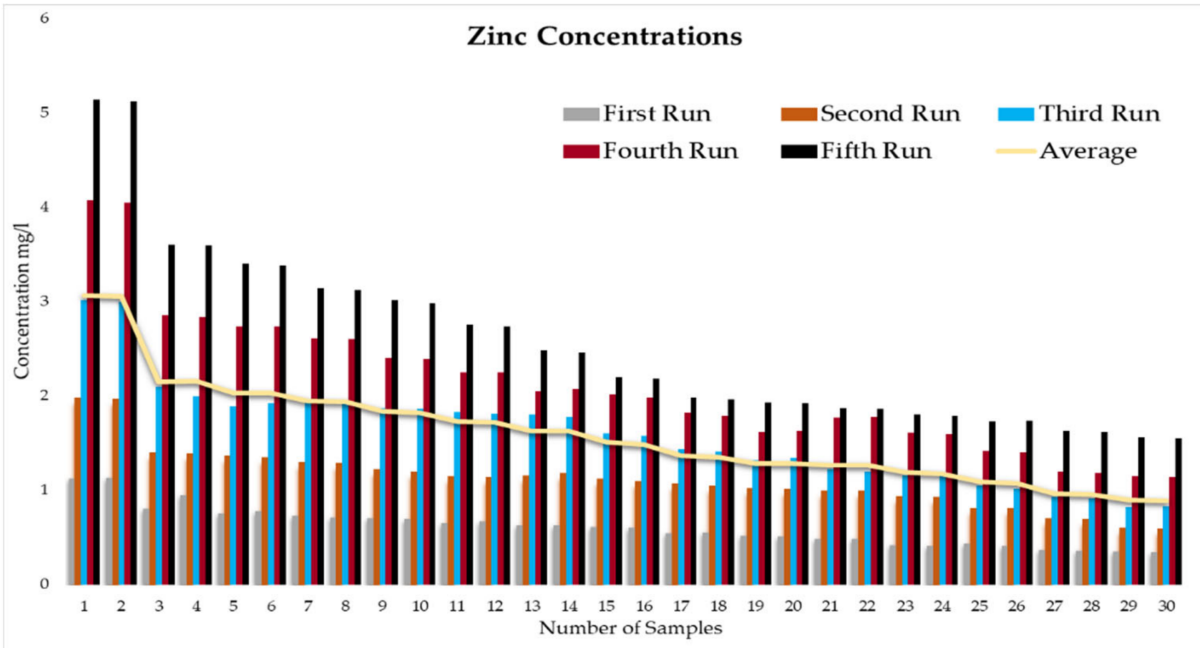

Figure 7. Zinc concentration in water samples from RBF model.

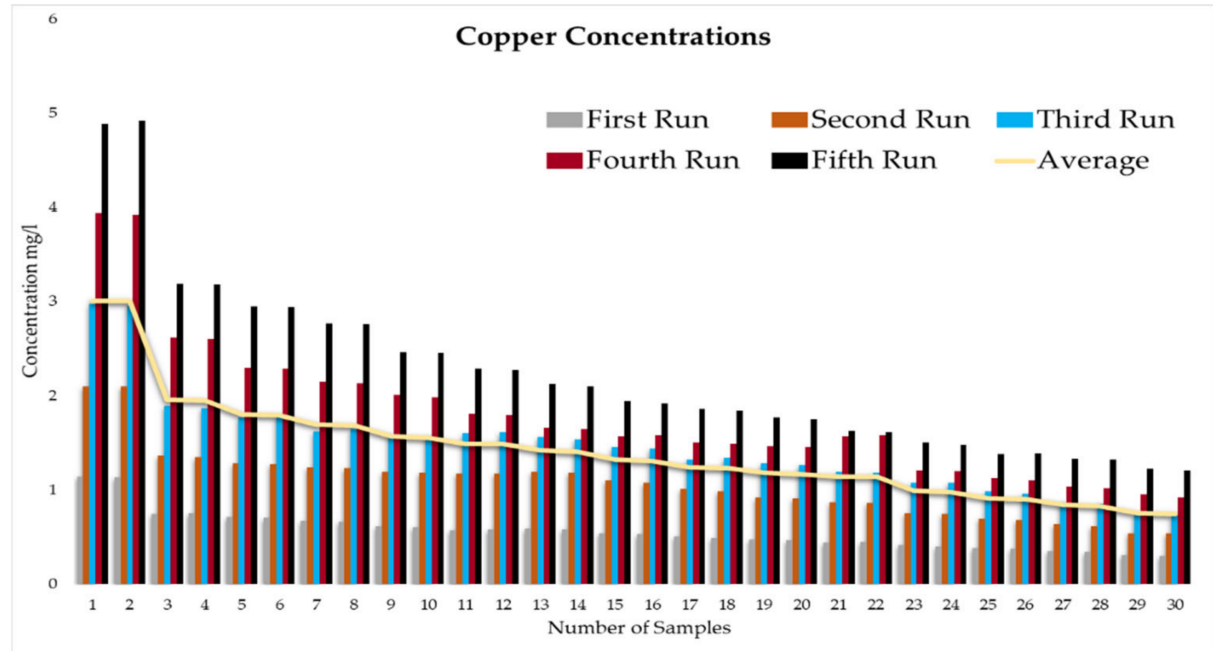

Figure 8. Copper concentration in water samples from RBF model. 


\section{Discussion}

\subsection{Water Quality}

The water quality has a very remarkable effect on the removal efficiency of heavy metals from water. The average water temperature during the experiments was $28 \pm 3{ }^{\circ} \mathrm{C}$, and we observed that the higher temperature enhanced the removal efficiencies. The $\mathrm{pH}$ value also ranged between 7 to 8 which does not have a high effect on the heavy metals concentrations in water. The BOD5 and COD concentration was slightly decreased by about 10 to $15 \%$, which may be due to its low initial value at the inlet of the RBF model.

\subsection{RBF Removal Efficiency}

Figure 9 displays simple calculations regarding the results of the five runs in the experiment. It includes the analysis of the previous section in terms of, maximum, minimum concentrations, and the percentage of heavy metals removal in each run. As shown in the following figure, the percentage of removal of the heavy metals reach $76.7 \%$ by using a natural treatment process, which is riverbank filtration.

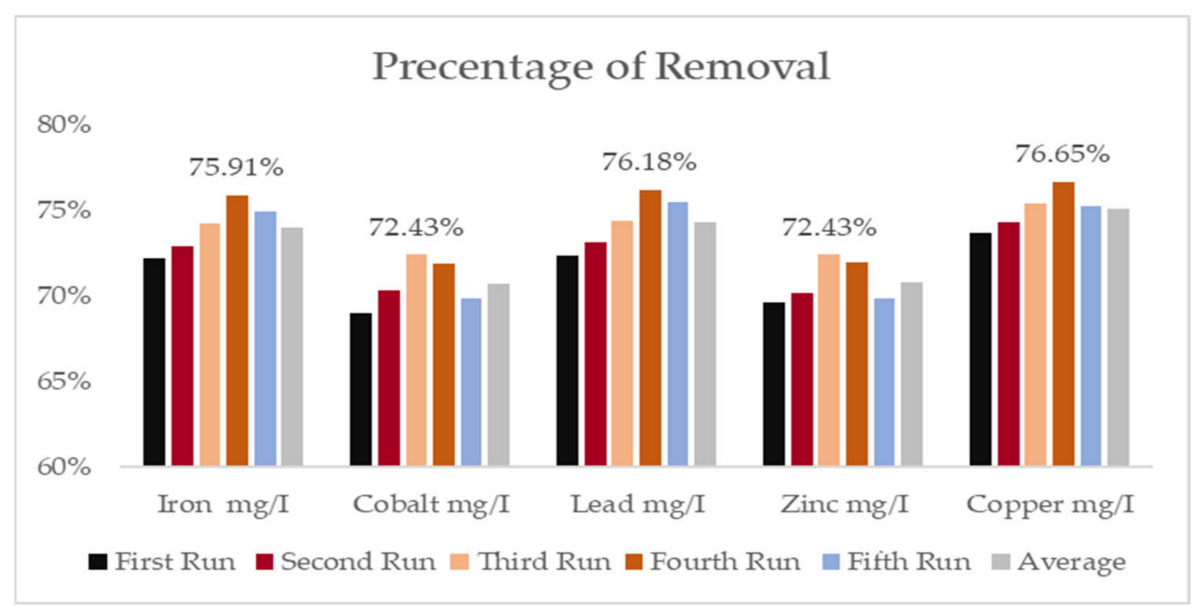

Figure 9. Removal efficiencies of heavy metals from water samples from RBF model.

An obvious decrease in the redox potential ORP was observed in the effluent water, which appears to be a reflection of the activity of bacteria to use metals in the soil such as iron Fe as a source of energy. Accordingly, we did not observe a significant effect of redox conditions on the efficiency of heavy metals removal from water using riverbank filtration.

\subsection{Analysis by Water Quality Index (WQI) Calculator}

By using this water quality index (WQI) calculator, we will identify how the quality of water from the River Nile improved by using the riverbank filtration process in each run in the experiment. This is done by adding the inlet values of iron, cobalt, zinc, copper, and lead in the standard values found in the calculator and the outlet values of the heavy metals in the actual measurement. In addition, the values of the other parameters were taken from physiochemical characteristics of the river Nile. Figure 10 shows a calculator phase calculating the WQI for the fourth run of the research study, as an example of determining the water quality of samples' results using the designed calculator. 


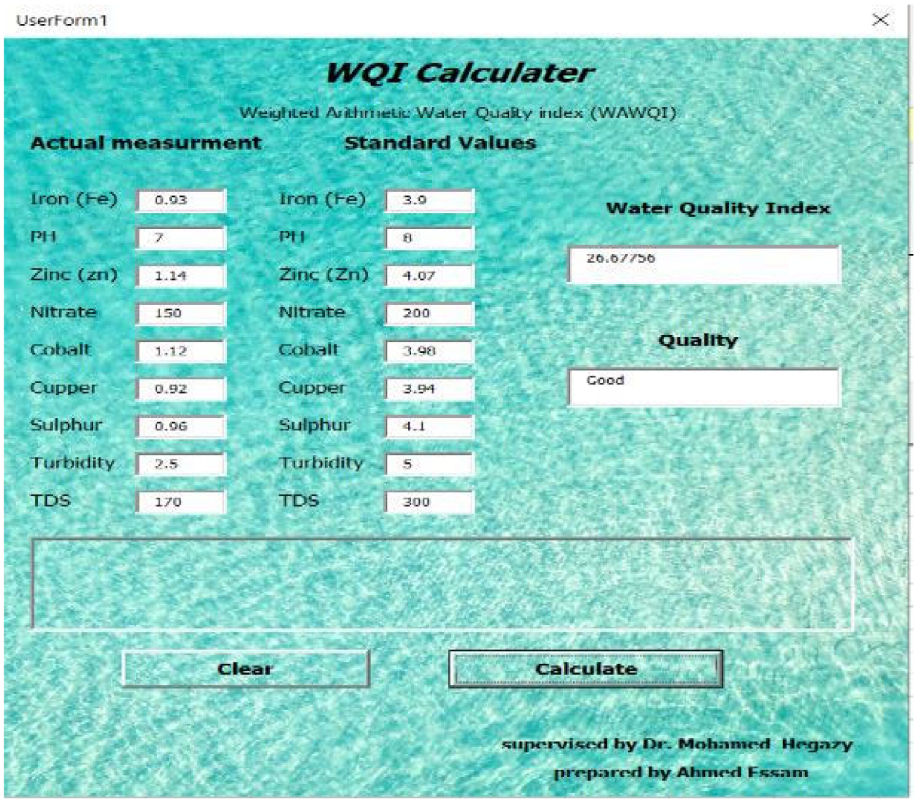

Figure 10. WQI calculator (Fourth run results).

The following Table 3 represents the five runs for each heavy metal that was used in the study. Based on the measured concentrations of heavy metal in each run, the WQI and WQ degree is calculated.

Table 3. The WQI calculator results from water samples from the RBF model.

\begin{tabular}{cccccc}
\hline & \multicolumn{5}{c}{ Percentage of Removal by RBF } \\
\cline { 2 - 6 } & First Run & Second Run & Third Run & Fourth Run & Fifth Run \\
\hline WQI & 28.9 & 28.4 & 27.5 & 26.7 & 28 \\
\hline WQ degree & Good & Good & Good & Good & Good \\
\hline
\end{tabular}

\section{Conclusions}

In Egypt, there is an increase in population and hence types of contaminations, for instance, fund pollution and accumulating pollution. These types of contaminations cause a negative effect on the quality of water due to the many parameters of water quality [31]. That is why the spreading need for drinkable water is increased compared to the past years. There are many characteristics or parameters of water quality, such as physical, chemical, and biological characteristics, and these water quality characteristics deicide if the water can be used or not [32]. There is a gap around the water demand and water supply not only in Egypt but in the world [33]; therefore, responsible authorities must improve and identify every detail in the water treatment process. Also, we must start to use effective and economical methods to purify the water, such as riverbank filtration. Many acceptable previous examples have proven that the RBF method is considered as a very effective method against heavy metals [20]. The efficiency of the RBF process in the removal of organic micropollutants is considerably affected by the redox conditions in the aquifer such as carbamazepine, and sulfamethoxazole.

The utilization of riverbank filtration has expanded widely in Egypt, especially in Upper Egypt. The use of riverbank filtration as an easy and natural purification technique has demonstrated that it is beneficial for removing many types of contaminations and heavy metals. RBF is considered as a regulatory system used to eliminate heavy metals and microorganisms and is environmentally friendly because of the absence of chemicals in this technique [34]. Governments and responsible parties must seek encouragement to use this process by doing the following: (1) Post guidelines or codes by specialist parties 
containing all requirements to reach the best outcomes. (2) Develop software, especially for RB systems, that contain good interface and various tools to make it easy to import all factors that affect the quality of RBF such as porosity of medium, temperature, quality of water. (3) Establish an institution concerned with RBF.

This research provides a detailed analysis of the riverbank filtration technique; it represents the outcome quality of the outlet water. To determine the outcomes of water quality, there are various procedures that can be done. There are two main lab experiments used to identify the power of RBF against heavy metals. The first experiment is applied to the soil located in the column of the RBF unit. Before placing the soil in the column, we must determine the properties and classification of the soil by using the soil classification test and permeability test. The second lab experiment is applied to determine the concentration of heavy metals of the outcome water samples by using a spectrophotometer.

In order to start the filtration process, the backwashing process, which will help in the maturation process to improve biological mechanisms during the filtration process, must be completed first. The filtration process is divided into five runs, and each run takes three days. The result-taking technique is performed as follows. First, we put a hundred liters on the CE 579-unit raw tank (this value is constant in all five runs). Then prepare the heavy metals in the lab. The concentration of heavy metals increases in each run or every three days. The results of the research's experiment show the average percentage of heavy metal removal for iron, cobalt, lead, zinc, and copper are $74.04 \%, 74.44 \%, 70.72 \%, 75.1 \%$, and $70.8 \%$, respectively.

After the outcome results of the experiments, the water quality was calculated by using the water quality index calculator that was mentioned previously. This program is designed to determine the quality of the resulting water that riverbank filtration units receive. The main objective of this software is to quickly calculate the water quality and water quality index without conducting many manual calculations, also to identify the parameter problems or to identify which parameter does not meet the requirements.

Author Contributions: Conceptualization, M.H.H. and A.Y.E.; data curation, M.H.H. and A.E.; formal analysis, M.H.H. and A.E.; investigation M.H.H. and E.E.H.; methodology M.H.H. and A.E.; project administration M.H.H.; resources, M.H.H. and A.E.; software, M.H.H. and A.E.; supervision, M.H.H., A.Y.E. and E.E.H.; validation, M.H.H. and A.E.; writing-original draft, M.H.H., A.E., A.Y.E. and E.E.H.; writing-review\& editing, M.H.H., A.E., A.Y.E. and E.E.H.; funding acquisition, E.E.H.; visualization, E.E.H. All authors have read and agreed to the published version of the manuscript.

Funding: This research was funded by TAIF UNIVERSITY RESEARCHERS SUPPORTING PROJECT, grant number "TURSP-2020/32".

Institutional Review Board Statement: Not applicable.

Informed Consent Statement: Not applicable.

Data Availability Statement: Not applicable.

Acknowledgments: The authors would like to acknowledge the financial support received from Taif University Researchers Supporting Project Number (TURSP-2020/32), Taif University, Taif, Saudi Arabia. Also, the authors would like to acknowledge the technical support received from the British University in Egypt (BUE).

Conflicts of Interest: The authors declare no conflict of interest.

\section{References}

1. Nagy-Kovács, Z.; Davidesz, J.; Czihat-Mártonné, K.; Till, G.; Fleit, E.; Grischek, T. Water Quality Changes during Riverbank Filtration in Budapest, Hungary. Water 2019, 11, 302. [CrossRef]

2. Wahaab, R.A.; Salah, A.; Grischek, T. Water Quality Changes during the Initial Operating Phase of Riverbank Filtration Sites in Upper Egypt. Water 2019, 11, 1258. [CrossRef]

3. Ghodeif, K.; Grischek, T.; Bartak, R.; Wahaab, R.; Herlitzius, J. Potential of river bank filtration (RBF) in Egypt. Environ. Earth Sci. 2016, 75, 671. [CrossRef] 
4. Jeyakumar, R.; Parimalarenganayaki, S.; Elango, L. Riverbank filtration for natural treatment of water in India: A review. Int. J. Civ. Eng. Technol. 2017, 8, 1203-1212.

5. Ahmed, A.K.A.; Marhaba, T.F. Review on riverbank filtration as an in-situ water treatment process. Clean Technol. Environ. Policy 2017, 19, 349-359. [CrossRef]

6. Hu, B.; Teng, Y.; Zhai, Y.; Zuo, R.; Li, J.; Chen, H. Riverbank filtration in China: A review and perspective. J. Hydrol. 2016, 541, 914-927. [CrossRef]

7. Inyinbor, A.; Adebsin, B.O.; Oluyori, A.; Akande, T.A.; Dada, A.O.; Toyin, A. Water pollution: Effects, prevention, and climatic impact. Water Chall. Urban. World 2018, 3, 35-50.

8. Peters, N.E.; Meybeck, M. Water Quality Degradation Effects on Freshwater Availability:Impacts of Human Activities. Water Int. 2000, 25, 185-193. [CrossRef]

9. Kachroud, M.; Trolard, F.; Kefi, M.; Jebari, S.; Bourrié, G. Water Quality Indices: Challenges and Application Limits in the Literature. Water 2019, 11, 361. [CrossRef]

10. Ukaogo, P.O.; Ewuzie, U.; Onwuka, C.V. Environmental Pollution: Causes, Effects, and the Remedies; INC: New York, NY, USA, 2020.

11. Sandhu, C.; Grischek, T.; Börnick, H.; Feller, J.; Sharma, S.K. A Water Quality Appraisal of Some Existing and Potential Riverbank Filtration Sites in India. Water 2019, 11, 215. [CrossRef]

12. Haas, R.; Opitz, R.; Grischek, T.; Otter, P. The AquaNES Project: Coupling Riverbank Filtration and Ultrafiltration in Drinking Water Treatment. Water 2018, 11, 18. [CrossRef]

13. Bhattacharjee, T.; Islam, M.; Chowdhury, D.; Majumdar, G. In-situ generated carbon dot modified filter paper for heavy metals removal in water. Environ. Nanotechnol. Monit. Manag. 2021, 16, 100582. [CrossRef]

14. Kazak, E.S.; Pozdniakov, S.P. Field study and reactive simulation of iron migration in groundwater during the riverbank filtration. Appl. Geochem. 2021, 124, 104817. [CrossRef]

15. Abdelrady, A.; Bachwenkizi, J.; Sharma, S.; Sefelnasr, A.; Kennedy, M. The fate of heavy metals during bank filtration: Effect of dissolved organic matter. J. Water Process. Eng. 2020, 38, 101563. [CrossRef]

16. Grischek, T.; Paufler, S. Prediction of Iron Release during Riverbank Filtration. Water 2017, 9, 317. [CrossRef]

17. Oberleitner, D.; Schulz, W.; Bergmann, A.; Achten, C. Impact of seasonality, redox conditions, travel distances and initial concentrations on micropollutant removal during riverbank filtration at four sites. Chemosphere 2020, 250, 126255. [CrossRef]

18. von Rohr, M.R.; Hering, J.G.; Kohler, H.-P.E.; von Gunten, U. Column studies to assess the effects of climate variables on redox processes during riverbank filtration. Water Res. 2014, 61, 263-275. [CrossRef]

19. Abdalla, F.A.; Shamrukh, M. Riverbank Filtration as an Alternative Treatment Technology . NATO Sc. Peace Secur. Ser. C Environ. Secur. 2011, 15, 281-298.

20. Shamrukh, M.; Abdel-Wahab, A. Riverbank filtration for sustainable water supply: Application to a large-scale facility on the River Nile. Clean Technol. Environ. Policy 2008, 10, 351-358. [CrossRef]

21. Henzler, A.F.; Greskowiak, J.; Massmann, G. Modeling the fate of organic micropollutants during river bank filtration (Berlin, Germany). J. Contam. Hydrol. 2014, 156, 78-92. [CrossRef] [PubMed]

22. Thomas, T.A.; Kani, K.M. Efficiency of Slow Sand Filter in Wastewater Treatment. Int. J. Sci. Eng. Res. $2016,7,312-317$.

23. Kuehn, W.; Mueller, U. Riverbank Filtration: An Overview. J. Am. Water Work. Assoc. 2000, 92, 60-69. [CrossRef]

24. Meng, L.; Zuo, R.; Brusseau, M.L.; Wang, J.; Liu, X.; Du, C.; Zhai, Y.; Teng, Y. Groundwater pollution containing ammonium, iron and manganese in a riverbank filtration system: Effects of dynamic geochemical conditions and microbial responses. Hydrol. Process. 2020, 34, 4175-4189. [CrossRef]

25. Paufler, S.; Grischek, T.; Bartak, R.; Ghodeif, K.; Wahaab, R.; Boernick, H. Riverbank filtration in Cairo, Egypt-Part II: Detailed investigation of a new riverbank filtration site with a focus on manganese. Environ. Earth Sci. 2018, 77, 318. [CrossRef]

26. Mumbi, A.W.; Fengting, L.; Karanja, A. Sustainable treatment of drinking water using natural coagulants in developing countries: A case of informal settlements in Kenya. Water Util. J. 2018, 18, 1-11.

27. UNHABITAT. Riverbank Filtration Project for Clean Water Production in Minya, Egypt; Project Brief About UN Habitat's Minya RBF Project; UNHABITAT: Nairobi, Kenya, 2009; p. 5.

28. Hegazy, M.H.; Assem, O. Reuse of water treatment sludge in coagulation process for the treatment of raw water from the river. $J$. Azhar. Univ. Eng. 2020, 15, 1002-1011. [CrossRef]

29. Nay, M.K. Experiment instructions: Interferometry. Depth Filtr. Lab. Manual. 2015, 3, 25-30.

30. Ghasemi, E.; Kaykhaii, M. Determination of zinc, copper, and mercury in water samples by using novel micro cloud point extraction and UV-Vis spectrophotometry. Eurasian J. Anal. Chem. 2017, 12, 313-324. [CrossRef]

31. Ghodeif, K.; Paufler, S.; Grischek, T.; Wahaab, R.; Souaya, E.; Bakr, M.; Abogabal, A. Riverbank filtration in Cairo, Egypt-part I: Installation of a new riverbank filtration site and first monitoring results. Environ. Earth Sci. 2018, 77, 270. [CrossRef]

32. Hamuna, B.; Tanjung, R.H.R.; Alianto, A. Assessment of Water Quality and Pollution Index in Coastal Waters of Mimika, Indonesia. J. Ecol. Eng. 2019, 20, 87-94. [CrossRef]

33. Mualla, W. Water Demand Management Is a Must in MENA Countries ... But Is It Enough? J. Geol. Resour. Eng. 2018, 6, 59-65. [CrossRef]

34. Shrikoti, A. Impact of River Bank Filtration on the Water Quality. Master's Thesis, Indian Institute of Technology Roorkee, Roorkee, India, 2016. 